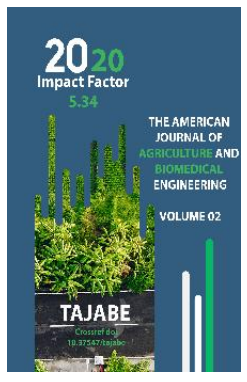

\section{Biological Features Of Glycyrriza Glabra L. Growing In The Vicinity Of Termez}

Dzhumaev Khudayberdi Kurbandurdiyevich

PhD In Biological Sciences, Docent At Termez State University, Uzbekistan

Fozilov Shershod Musurmonovich

Teacher At Termez State University, Uzbekistan

Copyright: Original

content from this work

may be used under the

terms of the creative

commons attributes

4.0 licence.

\title{
ABSTRACT
}

The article provides data on the aboveground and underground parts of Glycyrrhizaglabra L. Licorice, which grows on the floodplains of the Surkhandarya River (south of the Republic of Uzbekistan). The length of the main root of the plant reaches $104 \mathrm{~cm}$, the diameter is $6.6 \mathrm{~cm}$. The horizontal roots reach up to $103 \mathrm{~cm}$. The seed germination rate is low $-45.7 \%$, the germination energy on the 6th day is $16.7 \%$. The best way to reproduce is vegetative.

\section{KEYWORDS}

Seed germination, germination energy, whole 1000 seeds, vertical and horizontal roots, reproduction methods.

\section{INTRODUCTION}

There are 10-12 thousand species of medicinal plants on earth. The chemical, pharmacological and medicinal properties of more than 1000 plant species have been investigated. There are 577 species of medicinal plants in Uzbekistan [15].
Licorice naked - Glycyrrhizaglabra L. perennial herb of the legume family (Fabaceae). Representatives of this family are found in the temperate and subtropical zones of Eurasia and America, in North Africa and Australia. It grows wild in France, Italy, Southeast Europe (including Ukraine and Moldova), North Africa, West and Central Asia. [1,2,3]. 
Licorice is widely used as a medicinal, food and industrial plant as a foaming agent. Licorice roots have long been used in scientific and folk medicine in many countries, including Russia, as an expectorant, anti-inflammatory, anti-allergic, antiviral, antibacterial, lipidlowering agent. Licorice root powder is used in the pharmaceutical industry as a flavoring agent in the manufacture of medical supplies $[3,4,5,6$, and 7], tincture with laurel noble is part of complex anti-inflammatory therapy for the treatment of chronic bronchitis against the background of tuberculosis [8]. Furthermore, there have been found antioxidant properties in it [9]. 9 species grow in Central Asia, 5 of them are found in Uzbekistan.

\section{MATERIALS AND METHODS}

The material for this study was cenopopulations of Glycyrrhizaglabra L. growing at the confluence of the Surkhandarya and Amu Darya rivers (Surkhandarya region, Republic of Uzbekistan). This species forms numerous thickets on the banks of the Surkhandarya River.

When determining the quality of seeds for individual fractions and assessing the laboratory germination of seeds in room conditions was carried out according to the method of MK Firs ova [10], When studying the root system and determining the wet and air-dry mass of roots, the method of VA Rozhkov was used [11].

\section{RESULTS AND DISCUSSION}

Surkhandarya region of the Republic of Uzbekistan is located in the southernmost part of the country. It is also located in the southern part of Central Asia, its territory corresponds to the arid subtropical climate zone. The territory of the region is crossed by $37^{\circ} 10 \mathrm{l}-39^{\circ} \mathrm{O} 2 \mathrm{l}$ north latitude and $66^{\circ} 32 \mathrm{I}-68$ $25 \mathrm{l}$ east latitude lines [14].
Glycyrrhizin labra L. on the banks of the Surkhandarya River reaches a height of 40-200 $\mathrm{cm}$. Stems are erect, slightly branched, one licorice specimen can bear from 4 to 10 flowering shoots. Leaves are alternate, compound, pinnate, $12-14 \mathrm{~cm}$ long, consist of 5-7 pairs of oblong-ovate, whole-edged and sticky leaflets with a lower part, 2-4 cm long and $1-2 \mathrm{~cm}$ wide, petioles $3-4 \mathrm{~cm}$ long. The number of leaves on one shoot reaches 14 . Each shoot can form 3-10 inflorescences, the number of flowers in an inflorescence ranges from 7 to 36 . The corolla of the flower is pale purple, up to 7-12 mm in length. The fruit is a straight or curved pod, brown in color, up to $13 \mathrm{~cm}$ long, polyspermous, 6 - 8 seeds, 2.5 - 3.0 $\mathrm{mm}$ long and $2.0-2.5 \mathrm{~mm}$ wide. The entire 1000 seeds are $7.8-8.8 \mathrm{~g}$.

Under natural conditions, licorice propagates by seeds and vegetative, i.e. from the buds of the root system. Laboratory seed germination is low and amounts to $47.5 \%$, with germination energy on the sixth day $-16.7 \%$, field - $30 \%$. Therefore, the best way to grow licorice naked is considered to be vegetative.

The vegetation of Glycyrrhizaglabra L. begins in the second half of April, the beginning of flowering in May, mass flowering is observed in June. Fruiting of the plant begins in August, mass fruiting in September.

We measured the dimensions of the root system at a soil depth of up to $60 \mathrm{~cm}$, since when cultivating Glycyrrhizaglabra L., the raw material is harvested at this very depth $[12,13]$.

The root system has vertical and horizontal roots. The length of the main root (together with small roots) reaches $2-3 \mathrm{~m}$. The length of the thickened part of the vertical root (1-1.5 $\mathrm{cm}$ in diameter) reaches - up to $1 \mathrm{~m}$. The diameter of the vertical root at the root collar reaches $6.6 \mathrm{~cm}$, at a $30 \mathrm{~cm}$ depth of soil - up to $4.3 \mathrm{~cm}$, at $60 \mathrm{~cm}$ depth - up to $2.4 \mathrm{~cm}$, i.e. almost three times thinner than the root collar (Table

1). 
The American Journal of Agriculture and Boimedical Engineering (ISSN - 2689-1018)

Published: November 30, 2020 | Pages: 59-63

Table 1. Data on the root system of Glycyrrhizaglabra L. on the floodplains of the Surkhandarya River

\begin{tabular}{|c|c|c|c|c|c|c|}
\hline Endives & $\begin{array}{c}\text { Verticalroo } \\
\text { tlength, }\end{array}$ & $\begin{array}{c}\text { Rootcollardiam } \\
\text { eter, cm }\end{array}$ & \multicolumn{4}{|c|}{ Vertical root diameter at soil depth } \\
\cline { 3 - 7 } & 104 & 6.6 & 6.1 & 5.4 & 4.3 & 2.4 \\
\hline 1 & 98 & 3.6 & 2.9 & 2.8 & 2.3 & 1.2 \\
\hline 2 & 93 & 3.4 & 2.9 & 2.4 & 2.6 & 1.0 \\
\hline 3 & 76 & 3.3 & 2.8 & 2.4 & 2.1 & 0.9 \\
\hline 4 & 46 & 3.2 & 2.6 & 2.3 & 1.9 & 1.0 \\
\hline 5 & & & & & & \\
\hline
\end{tabular}

Data on the diameter of horizontal roots are shown in Table 2. The number of horizontal roots per individual ranges from 3 to 9 , length - up to $103 \mathrm{~cm}$, diameter at the point of departure from the main root - up to $3.4 \mathrm{~cm}$, at a distance of $60 \mathrm{~cm}$ from the main root - up to $2.3 \mathrm{~cm}$.

Table 2. Diameter of horizontal roots of Glycyrrhizaglabra L.

\begin{tabular}{|c|c|c|c|c|c|c|c|}
\hline \multirow{3}{*}{ Bodies } & \multicolumn{2}{|c|}{ Horizontal roots } & \multirow{3}{*}{$\begin{array}{l}\text { At the } \\
\text { point of } \\
\text { departure } \\
\text { from the } \\
\text { main root }\end{array}$} & \multirow{2}{*}{\multicolumn{4}{|c|}{$\begin{array}{c}\text { Diameter of horizontal roots at a } \\
\text { distance from the main root) }\end{array}$}} \\
\hline & \multirow{2}{*}{$\begin{array}{l}\text { Amount on } \\
\text { per one } \\
\text { body }\end{array}$} & \multirow[b]{2}{*}{$\begin{array}{l}\text { Length } \\
\qquad, \mathrm{cm}\end{array}$} & & & & & \\
\hline & & & & $10 \mathrm{~cm}$ & $20 \mathrm{~cm}$ & $30 \mathrm{~cm}$ & $60 \mathrm{~cm}$ \\
\hline 1 & 9 & 87 & 2.7 & 2.6 & 2.4 & 2.1 & 1.9 \\
\hline 2 & 6 & 71 & 2.4 & 2.1 & 1.9 & 1.5 & 0.8 \\
\hline 3 & 8 & 103 & 3.4 & 3.1 & 2.9 & 2.6 & 2.3 \\
\hline 4 & 3 & 49 & 2.4 & 1.6 & 1.6 & 1.1 & 0.5 \\
\hline 5 & 4 & 43 & 2.1 & 1.6 & 1.4 & 1.0 & 0.4 \\
\hline
\end{tabular}


Table 3. Results of drying the roots of Glycyrrhizaglabra L.

\begin{tabular}{|c|c|c|}
\hline Bodies & Freshweight, g & Airdryweight, g \\
\hline 1 & 2700 & 1130 \\
\hline 2 & 2500 & 1080 \\
\hline 3 & 1400 & 750 \\
\hline 4 & 900 & 560 \\
\hline 5 & 700 & 380 \\
\hline
\end{tabular}

As can be seen from the data in Table 3, from each plant of licorice naked, you can collect from 700 to 2700 grew, or from 380 to $1130 \mathrm{~g}$ air-dries mass of raw materials.

To obtain raw materials and preserve natural thickets, it can be cultivated. Licorice naked is an unpretentious plant, it can be grown in abandoned and saline places, unsuitable for other crops. On plantations, it can be reproduced vegetative using rhizomes, since field germination of seeds is very low - $30 \%$.

According to our calculations, if we plant rhizomes between rows $60 \mathrm{~cm}$ and between plants $50 \mathrm{~cm}$, then on each hectare of grown licorice plants, up to 33,000 plants can be grown. From each hectare of such licorice plantations it will be possible to obtain up to 89.6 tons of wet root mass.

\section{CONCLUSIONS}

1. Licorice naked on the floodplain of the Surkhandarya River grows in groups and forms pure populations. In addition, the plant is found along streams and drainage ditches, swampy, abandoned, saline places, unsuitable for growing crops.

2. To harvest licorice roots, you can use natural thickets, but to preserve this unique plant population, you need a part of the territory that can be grown.
3. Laboratory germination of licorice seeds is $47.5 \%$, with germination energy on the sixth day $-16.7 \%$, field $-30 \%$.

4. Vegetation of the plant begins in the second half of April, the phase of mass flowering is observed in June. The beginning of seed ripening is observed in August; mass ripening - in September.

5. Vertical roots of licorice reach up to $2-3 \mathrm{~m}$, the diameter of the rhizome on the root collar - up to $6.6 \mathrm{~cm}$, at $60 \mathrm{~cm}$ soil depth up to $2.4 \mathrm{~cm}$.

6. From each hectare of licorice plantations, you can get up to 89.6 tons of wet roots mass.

\section{REFERENCES}

1. Korotkova E.E. Genus Glycyrrhiza L. Licorice. Flora of Uzbekistan. // Tashkent, 1978. p. 825-717.

2. Alekseeva T.B. State of the Licorice naked population in Kalmykia. // Scientific Thought of the Caucasus, 2006, Special Issue No. 5, pp. 159-83.

3. Tolstikov GA et al. Licorice: biodiversity, chemistry, application in medicine // Novosibirsk: Academic publishing house "GEO", 2006. -311 p.

4. Alekseeva T.B. Ecological, cenotic and biochemical features of naked licorice (Glycyrrhizaglabra L.) in Kalmykia: author. 
dis. ... Cand. biol. Sciences: 03.00.16. I Saratov, 2007. - 20 p.

5. Dudchenko L.G. Spicy-aromatic and spicyflavoring plants: Handbook / $\mathrm{K}$.: NaukovaDumka, 1989. p. 304-211.

6. Karomatov I. D. Licorice, licorice, licorice use in medicine.

1. // Actual problems of the humanities and natural sciences. No. 11-2, 2013. p. 337-230.

7. Nazarova G.N., Maslov A.K., Sukhenko L.T., Luzhnova S.A. Background of the use of extract from licorice root (Glycyrrhizaglabra) in the therapy of leprosy. // Bulletin of new medical technologies - 2008; T. XV, No. 2: p. 256218.

8. Veliev P.M. A method of treating chronic bronchitis against the background of tuberculosis using alcohol tincture of licorice with noble laurel. // "International scientific review of the problems and prospects of modern science and education". / Boston. USA. February 21-22, 2019. P. 99-70.

9. Dinesh Dhingra, Milind Parle, S.K. Kulkarni. Memory enhancing activity of Glycyrrhizaglabra in mice. // Journal of Ethonopharmacology. V.91. Issues 2-3, April 2004, Pages 388-361.

10. Firsova M.K. Research methodology and assessment of seed quality. I $\mathrm{M}$ : Selkhozgiz, 1955 -- 376 p.

11. Rozhkov V.A., Kuznetsova I.V., RakhmatulloevKh.R. Methods for studying the root systems of plants in the field and in the laboratory: textbook. allowance. 2nd ed. / M.: GOU VPO MGUL, 2008. - 51 p.

12. Ataev S.A., KeldzhaevP.Sh. Possibilities of growing licorice around the Turkmen lake in the Karakum. Desert development problems. / Ashgabat, 2014, No. 3-4, p. 9764.

13. Kerbabaev B.B., Gladyshev A.I., KeldzhaevTs.Sh., Geyushova T.M. Licorice culture in Turkmenistan: taxonomy, bioecology, introduction to culture. Ashgabat: Ylym, 1989 --- 191 p.
14. Begmatov A. M., Sattarov A.S. Bioecological properties of Stevia rebaudiana Bertoni in introduction conditions. The American Journal of Agriculture and Boimedical Engineering. Volume 2 Issue 10, 2020. -P. 63-68.

15. Sattarov A.S., Begmatov A. M. Bioecology of melissa officinalis plant In Introduction conditions. The American Journal of Agriculture and Boimedical Engineering. Volume 2 Issue 10, 2020. -P. 69-73. 